\title{
Characterization of Physicochemical and Spectroscopic Properties of Biofield Energy Treated Bio Peptone
}

\author{
Mahendra Kumar Trivedi ${ }^{1}$, Alice Branton ${ }^{1}$, Dahryn Trivedi ${ }^{1}$, Gopal Nayak ${ }^{1}$, Khemraj Bairwa ${ }^{2}$, \\ Snehasis Jana ${ }^{2, *}$ \\ ${ }^{1}$ Trivedi Global Inc., Henderson, NV, USA \\ ${ }^{2}$ Trivedi Science Research Laboratory Pvt. Ltd., Bhopal, Madhya Pradesh, India
}

Email address:

publication@trivedisrl.com (S. Jana)

\section{To cite this article:}

Mahendra Kumar Trivedi, Alice Branton, Dahryn Trivedi, Gopal Nayak, Khemraj Bairwa, Snehasis Jana. Characterization of Physicochemical and Spectroscopic Properties of Biofield Energy Treated Bio Peptone. Advances in Bioscience and Bioengineering.

Vol. 3, No. 6, 2015, pp. 59-66. doi: 10.11648/j.abb.20150306.12

\begin{abstract}
Bio peptone is a combination of enzymatic digest of animal tissues and casein; and generally used for the growth of several varieties of microbes. The aim of present study was to investigate the impact of biofield energy treatment on the physicochemical and spectroscopic properties of bio peptone. The present study was carried out in two groups i.e. control and treated. The control group was kept without treatment, while the treated group was subjected to Mr. Trivedi's biofield energy treatment. Subsequently, both the samples were assessed using numerous analytical techniques. The X-ray diffractograms (XRD) showed the halo patterns of XRD peaks in both the samples. The particle size analysis exhibited about $4.70 \%$ and $17.58 \%$ increase in the $\mathrm{d}_{50}$ (average particle size) and $\mathrm{d}_{99}$ (particle size below which $99 \%$ particles are present), respectively of treated bio peptone as compared to the control. The surface area analysis revealed the $253.95 \%$ increase in the specific surface area of treated sample as compared to the control. The differential scanning calorimetry (DSC) analysis showed the $29.59 \%$ increase in the melting temperature of treated bio peptone sample as compared to the control. Thermogravimetric analysis (TGA) showed the increase in onset of degradation temperature by $3.31 \%$ in the treated sample with respect to the control. The Fourier transform infrared (FT-IR) study revealed the changes in the wavenumber of functional groups such as O-H stretching from $3066 \mathrm{~cm}^{-1}$ to $3060 \mathrm{~cm}^{-1}$; C-H stretching from 2980, 2893, and $2817 \mathrm{~cm}^{-1}$ to 2970, 2881, and $2835 \mathrm{~cm}^{-1}$, respectively; N-H bending from 1589 $\mathrm{cm}^{-1}$ to $1596 \mathrm{~cm}^{-1} ; \mathrm{C}=\mathrm{C}$ stretching from $1533 \mathrm{~cm}^{-1}$ to $1525 \mathrm{~cm}^{-1}$; and $\mathrm{P}=\mathrm{O}$ stretching from $1070 \mathrm{~cm}^{-1}$ to $1078 \mathrm{~cm}^{-1}$ in treated sample as compared to the control. The UV-vis spectroscopy showed the similar patterns of absorbance maxima $\left(\lambda_{\max }\right)$ i.e. at 259 $\mathrm{nm}$ and $257 \mathrm{~nm}$ in both the control and treated samples, respectively. Overall, the analytical results suggested that Mr. Trivedi's biofield energy treatment has substantial effect on physicochemical and spectral properties of bio peptone. Owing to this, the treated bio peptone might be more effective as culture medium than the corresponding control.
\end{abstract}

Keywords: Bio Peptone, Biofield Energy Treatment, X-Ray Diffraction, Particle Size Analysis, Surface Area Analysis, Thermogravimetric Analysis, Fourier Transform Infrared Spectroscopy

\section{Introduction}

A culture or growth medium is a liquid or gel, which is intended to support the growth of microorganism or cell [1]. The culture media can be classified in several categories based on their physical form (solid media or liquid media), and chemical composition (chemically defined or synthetic media and complexed media), etc. In addition, some specific or selective media are also there; the special media contains various chemicals designed to distinguish the microbes by the appearances of their colonies $[2,3]$. The selective media contains elements that inhibit the growth of some kinds of microbes and at the same time, it promotes the growth of other microbes [4]. Similarly, the bio peptone is a mixture of enzymatic digest of animal tissues and casein. It is processed cautiously to enhance the nutritive values for proper growth requirement of wide variety of microorganisms. It offers a wide spectrum of amino acids and peptides and therefore can be used in numerous culture media preparation [5]. The bio peptone meets the nutritional requirements, which are not provided by meat peptone or casein hydrolysate individually. It can also be used for the culture of fastidious microorganisms 
and production of enzymes, antibiotics, and other microbiological origin products [6].

Sterilization process plays a significant role on the quality of culture media. The autoclaving is the standard method of culture media sterilization [7]. However, the heat treatment of complex culture media may result in destruction of the nutrients either by direct thermal degradation or by the chemical reactions among the components [8]. Hence, a technique is required, which can enhance the overall stability of the bio peptone [9].

In the recent past years, the energy therapies have been reported for beneficial effects in several field throughout the word [10]. Biofield energy treatment is one of the energy therapies [11]. The energy medicines have been categorized under the Complementary and Alternative Medicine (CAM) therapies by National Institute of Health (NIH)/National Center for Complementary and Alternative Medicine (NCCAM) [12]. Consciousness is one of the possible mechanisms among the several proposed one to support the biofield energy therapies. It includes healer's intent to heal, and may interact with the physical realm [13]. Similarly, physical resonance is another theory, which comprises subtle energies. As per the physical resonance theory, the energy can be exchanged between the energy fields of healer and patient [14]. Mr. Mahendra Kumar Trivedi is a renowned practitioner of energy medicine. He can harnesses the energy from universe and transfers it to the object (living or non-living); this procedure is termed as biofield energy treatment (The Trivedi Effect $\left.{ }^{\circledR}\right)$. The Trivedi Effect ${ }^{\circledR}$ has been studied in the several fields such as agricultural science research [15], microbiology research [16], and biotechnology research [17], etc. In addition, Mr. Trivedi's biofield energy treatment has been also reported to alter the various physicochemical properties of organic products [18] and organic compounds [19].

Based on the above mentioned literature reports on biofield energy treatment and the uses of bio peptone in the culture media, the present study was designed to investigate the effect of biofield energy treatment on bio peptone. The treated bio peptone was analyzed using several analytical techniques to assess any modification in its physicochemical and spectroscopic properties. The data of treated sample were compared with that of control sample.

\section{Experimental}

\subsection{Materials}

Bio peptone was procured from HiMedia Laboratories, India.

\subsection{Biofield Energy Treatment Modalities}

The bio peptone sample was divided into two parts: control and treated. The control sample was kept without treatment, while the treated sample was handed over in sealed pack to $\mathrm{Mr}$. Trivedi for the biofield energy treatment. Mr. Trivedi provided the biofield energy treatment to the treated group via his unique thought transmission process without touching the sample under standard laboratory conditions. After treatment, the treated samples were stored at standard laboratory conditions, and subsequently, both the treated and control samples were evaluated using several analytical techniques such as X-ray diffractometry (XRD), particle size analysis, surface area analysis, differential scanning calorimetry (DSC), thermogravimetric analysis/derivative thermogravimetry (TGA/DTG), Fourier transform infrared (FT-IR), and UV-vis spectroscopy.

\subsection{XRD Study}

The XRD study of control and treated bio peptone samples was carried out on Phillips (Holland PW 1710) X-ray diffractometer. The XRD instrument was equipped with nickel filter and copper anode. The XRD analysis was done at the wavelength of $1.54056 \AA$.

\subsection{Particle Size Analysis}

The particle size of control and treated bio peptone sample was measured using the laser particle size analyzer (Sympatec HELOS-BF). The detection range of instrument was set in the range of $0.1-875 \mu \mathrm{m}$. The raw data were obtained in the chart form with particle size on $\mathrm{x}$-axis and cumulative percentage on $y$-axis. The percent alteration in particle size was inferred using the following equation.

$$
\begin{aligned}
& \% \text { change in particle size, } d_{50}= \\
& \frac{\left[\left(d_{50}\right)_{\text {Treated }}-\left(d_{50}\right)_{\text {Control }}\right]}{\left(d_{50}\right)_{\text {Control }}} \times 100
\end{aligned}
$$

Where, $\left(\mathrm{d}_{50}\right)_{\text {Control }}$ and $\left(\mathrm{d}_{50}\right)$ Treated are the average particle size of control and treated samples, respectively; correspondingly the $\mathrm{d}_{99}$ was calculated.

\subsection{Surface Area Analysis}

The surface area of control and treated bio peptone was determined using the ASTM D 5604 method on BrunauerEmmett-Teller (BET) surface area analyzer (Smart SORB 90). The instrument range was set from $0.2 \mathrm{~m}^{2} / \mathrm{g}$ to $1000 \mathrm{~m}^{2} / \mathrm{g}$. The percent change in the surface area of treated sample with respect to the control was calculated using the following equation.

$\%$ change in surface area $=\frac{\left[\mathrm{S}_{\text {Treated }}-\mathrm{S}_{\text {Control }}\right]}{\mathrm{S}_{\text {Control }}} \times 100$

Here, $\mathrm{S}_{\text {Control }}$ and $\mathrm{S}_{\text {Treated }}$ is the surface area of control and treated samples, respectively.

\subsection{DSC Study}

The melting temperature of control and treated bio peptone was determined using the Pyris-6 Perkin Elmer differential scanning calorimeter. In this experiment, the analytes were heated at the rate of $10^{\circ} \mathrm{C} / \mathrm{min}$ under the air atmosphere with the flow rate of $5 \mathrm{~mL} / \mathrm{min}$. An empty pan sealed with cover lid was used as the reference pan. The melting temperature $\left(\mathrm{T}_{\mathrm{m}}\right)$ 
of both the control and treated samples were obtained from the DSC thermograms.

\subsection{TGA/DTG Analysis}

The TGA/DTG analysis of both control and treated bio peptone samples were performed on Mettler Toledo simultaneous TGA/DTG analyzer. The analytes were heated up to $400^{\circ} \mathrm{C}$ (at the rate of $5^{\circ} \mathrm{C} / \mathrm{min}$ ) from room temperature under the air atmosphere. The onset temperature of thermal degradation and temperature at which maximum weight loss occurred $\left(\mathrm{T}_{\max }\right)$ in samples were found from the TGA/DTG thermograms.

\subsection{FT-IR Spectroscopic Analysis}

The FT-IR spectroscopic analysis of both the control and treated bio peptone samples were carried out to evaluate the effect of biofield energy treatment on molecular levels like force constant and bond strength in chemical structure [20]. The samples for FT-IR spectroscopy were prepared by crushing the powdered bio peptone sample with $\mathrm{KBr}$ into fine powder and then pressing into pellets. The FT-IR spectra were obtained from the Shimadzu's Fourier transform infrared spectrometer (Japan) in the frequency region of 500-4000 $\mathrm{cm}^{-1}$.

\subsection{UV-Vis Spectroscopic Analysis}

The spectra of control and treated bio peptone samples were recorded on Shimadzu UV spectrometer (2400 PC). The UV spectrometer was equipped with quartz cell of $1 \mathrm{~cm}$ with a slit width of $2.0 \mathrm{~nm}$, and the wavelength was set to $200-400 \mathrm{~nm}$.

\section{Results and Discussion}

\subsection{XRD Analysis}

The XRD diffractograms of control and treated bio peptone samples are shown in Fig. 1. It showed the broad halo at $2 \theta$ equals to $21^{\circ}$ in both the samples. These halo patterns of XRD peaks suggested the amorphous nature of both control and treated samples [21]. The XRD study suggested that biofield energy treatment did not induce any changes in the crystal structure of bio peptone with respect to the control sample. Amorphous material is the noncrystalline solid in which the atoms and molecules are unorganized in a definite lattice pattern [22]. They did not possess the long-range order of atomic positions in crystals, but retain the short-range order typical of liquids. The amorphous form of solid is more soluble in water and other solvent and relatively stable than the crystalline solids [23].

\subsection{Particle Size Analysis}

The average particle size $\left(\mathrm{d}_{50}\right)$ and the particle size below which $99 \%$ particles are present $\left(d_{99}\right)$ in control and treated samples were determined by laser particle size analyzer, and results are shown in Fig. 2. It showed the $\mathrm{d}_{50}$ values as 12.56 $\mu \mathrm{m}$ and $13.15 \mu \mathrm{m}$ in control and treated samples, respectively.
The $\mathrm{d}_{99}$ values were observed as $107.74 \mu \mathrm{m}$ and $126.68 \mu \mathrm{m}$, in control and treated samples, respectively. The results showed about $4.70 \%$ increase in the $d_{50}$ and $17.58 \%$ increase in the $d_{99}$ values of treated bio peptone with respect to the control bio peptone.

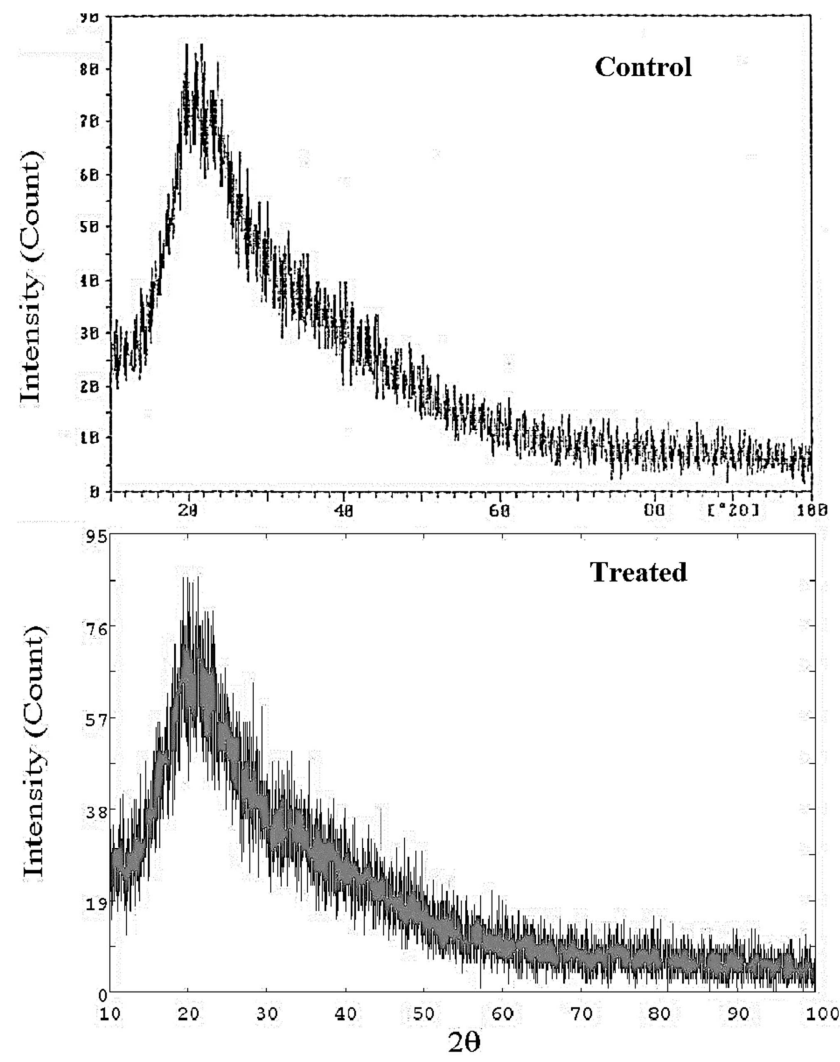

Figure 1. XRD diffractograms of control and treated bio peptone.

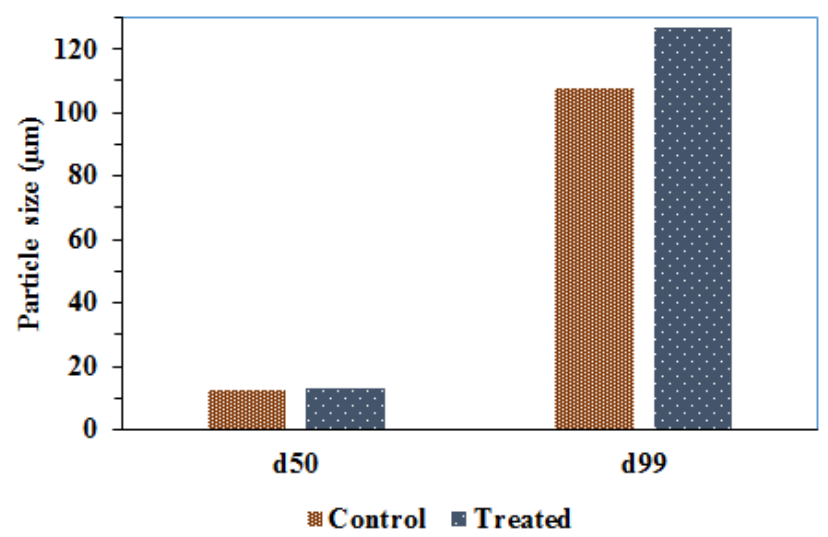

Figure 2. Particle size of control and treated bio peptone.

It is supposed that the biofield energy possibly induce the agglomeration process in treated bio peptone molecules that leads to increases of particle sizes $\left(\mathrm{d}_{50}\right.$ and $\left.\mathrm{d}_{99}\right)$ of treated sample. Recently, a biofield-induced alteration in the particle sizes of bile salt and proteose peptone have been reported by our group [24].

\subsection{Surface Area Analysis}

The surface areas of control and treated bio peptone samples 
were determined with the help of BET surface area analyzer. The surface area of control and treated samples was observed as $0.2758 \mathrm{~m}^{2} / \mathrm{g}$ and $0.9762 \mathrm{~m}^{2} / \mathrm{g}$, respectively. The result exhibited significant increase in surface area by $253.95 \%$ in the treated sample as compared to the control bio peptone (Fig. 3). It is reported that surface area is inversely proportional to the particle size [25]. However, in this study both the particle size and surface area were increased, which was contrary. This is possible when the porosity induces or increases in the particles, which leads to increase in the effective surface area [26]. Furthermore, due to increases in surface free energy, the particles aggregate to form the larger particles, which also cause to increase in the particle size with increase in the surface area [27]. Based on this, it is presumed that biofield energy probably induced the aggregation of bio peptone particle with enhanced porosity, which may lead to increase the particle size as well as the surface area of treated sample with respect to the control.

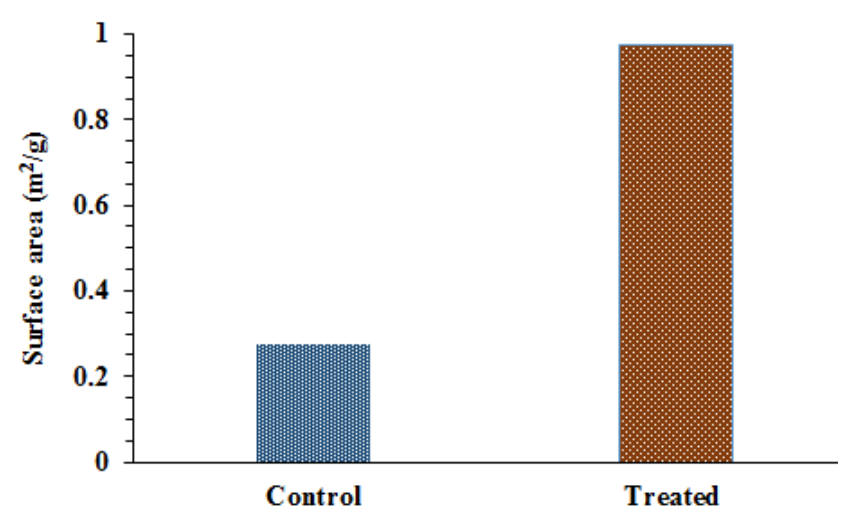

Figure 3. Surface area of control and treated bio peptone.

\subsection{DSC Analysis}

DSC analysis was carried out to determine the melting temperature of bio peptone (control and treated). DSC thermograms of control and treated bio peptone are presented in Fig. 4. The melting temperatures of control and treated bio peptone were observed as $155.29^{\circ} \mathrm{C}$ and $201.24^{\circ} \mathrm{C}$, respectively.

The results showed a significant increase $(29.59 \%)$ in the melting temperature of treated sample with respect to the control (Table 1). This increase in the melting temperature might be correlated to the enhanced thermal stability [28, 29]. The melting point of treated sample might increase due to increase in the particle size [30]. Furthermore, the stronger intermolecular attractions lead to higher melting points [31]. Based on this, it is hypothesized that the biofield energy treatment increased the intermolecular interaction in bio peptone molecules, which resulted into enhanced melting temperature with respect to the untreated sample. The thermal study suggested that the treated bio peptone might be more thermally stable than the control sample.
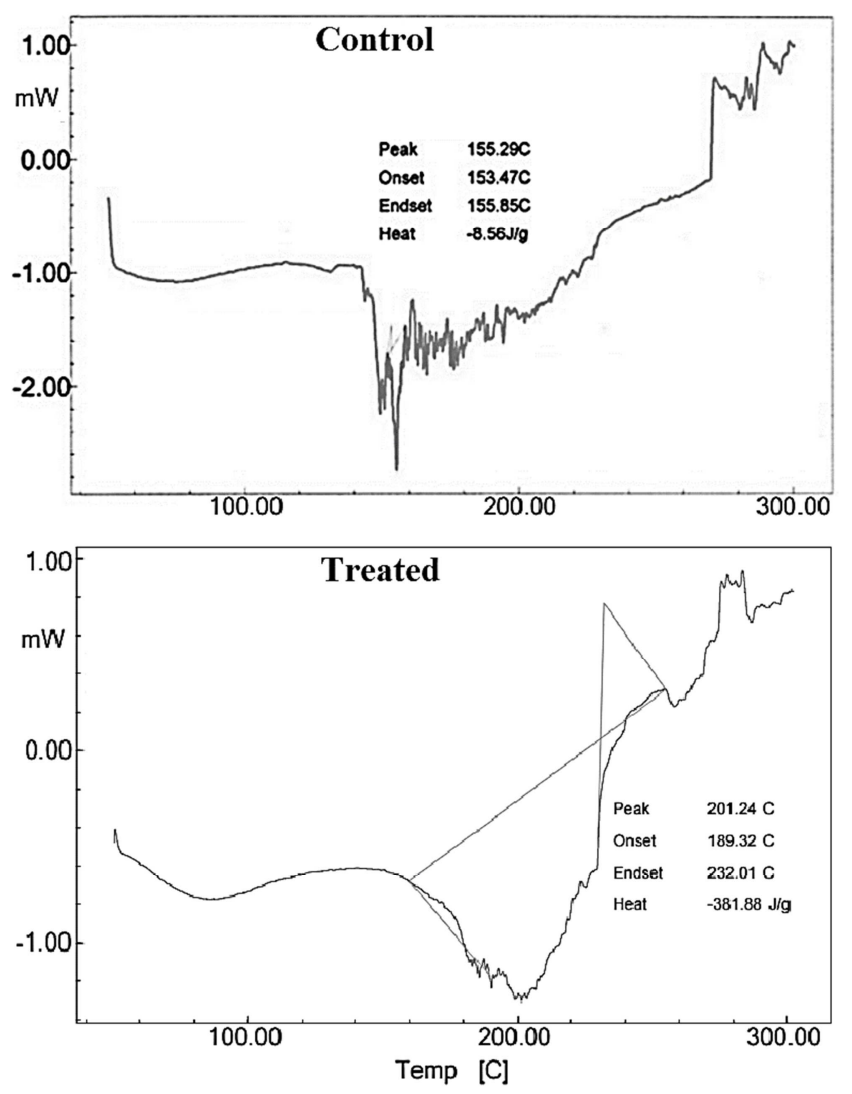

Figure 4. DSC thermograms of control and treated bio peptone.

Table 1. Thermal analysis of control and treated samples of bio peptone.

\begin{tabular}{ccc}
\hline Parameter & Control & Treated \\
\hline Melting point $\left({ }^{\circ} \mathrm{C}\right)$ & 155.29 & 201.24 \\
Onset temperature $\left({ }^{\circ} \mathrm{C}\right)$ & 181.00 & 187.00 \\
$\mathrm{~T}_{\max }\left({ }^{\circ} \mathrm{C}\right)$ & 269.12 & 217.77 \\
\hline
\end{tabular}

$\mathrm{T}_{\max }$ : temperature at which maximum weight loss occurs

\subsection{TGA/DTG Analysis}

The TGA/DTG thermograms of control and treated bio peptone samples are shown in Fig. 5, and data are reported in Table 1. The TGA thermogram of control sample showed a broad single step of thermal degradation pattern. The sample started to degrade from $181^{\circ} \mathrm{C}$ (onset temperature) and terminated at $355^{\circ} \mathrm{C}$ (endset temperature). On the other hand, the treated sample showed the two steps of thermal degradation; the first step was initiated from $187^{\circ} \mathrm{C}$ and ended at $245^{\circ} \mathrm{C}$. The second step was started from $261^{\circ} \mathrm{C}$ and terminated at about $369^{\circ} \mathrm{C}$. The result showed the slight increase $(3.31 \%)$ in the onset temperature of thermal degradation in the treated sample with respect to the control. This might be correlated to the increased thermal stability of the treated sample as compared to the control [32]. Based on this it is depicted that the biofield treated bio peptone is more thermally stable than the control sample. 

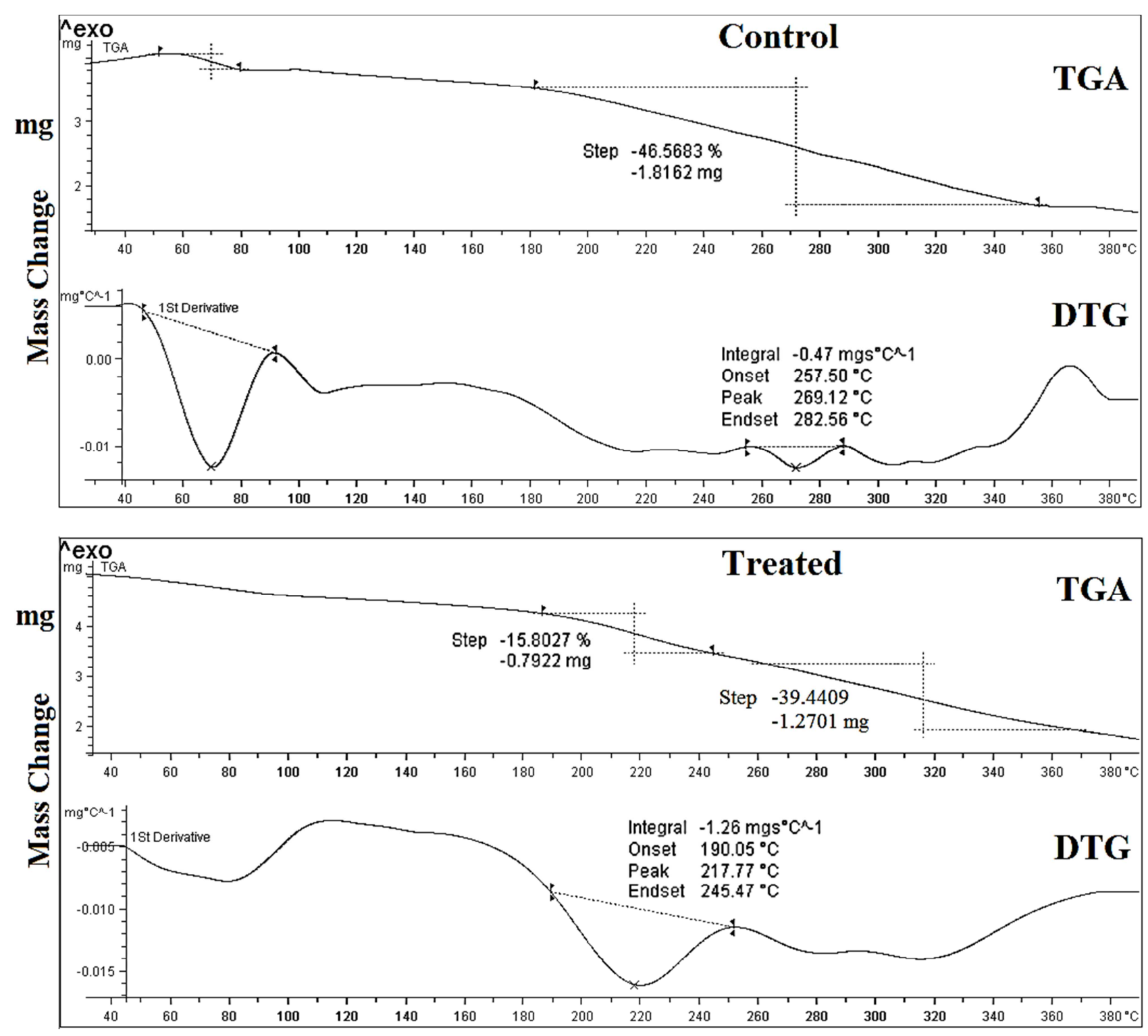

Figure 5. TGA/DTG thermogram of control and treated bio peptone.

\subsection{FT-IR Spectroscopic Characterization}

The FT-IR spectra of both the control and treated bio peptone are shown in Fig. 6. The bio peptone is the mixture of enzymatic digest of animal tissues and casein, which contains several proteins, phosphoproteins, minerals, amino acids, etc. [6]. Due to the presence of these diverse components, the FT-IR spectra may contain several vibrational peaks such as amide $(\mathrm{N}-\mathrm{H}, \mathrm{C}=\mathrm{O})$, aromatic ring $(\mathrm{C}-\mathrm{H}, \mathrm{C}=\mathrm{C})$ etc. The FT-IR spectrum of control sample showed the broad vibrational peak at $3066 \mathrm{~cm}^{-1}$ that may be due to O-H or N-H stretching of amino acids. This peak was appeared at the slight downstream frequency region i.e. at $3060 \mathrm{~cm}^{-1}$ in the treated sample. It is well known that the stretching frequency of any functional group or bond is directly proportional to the force constant [33]. Therefore, it is anticipated that biofield energy treatment might decrease the dipole moment of O-H or N-H bond in the treated sample of bio peptone as compared to the control. Hence, the force constant and bond strength of $\mathrm{O}-\mathrm{H}$ or N-H group might decrease in the treated sample as compared to the control. Further, the vibration peaks at 2980, 2893, and $2817 \mathrm{~cm}^{-1}$ in the control sample might be attributed to the $\mathrm{C}-\mathrm{H}$ stretching. These peaks were correspondingly observed at the frequency region of 2970,2881 , and $2835 \mathrm{~cm}^{-1}$ in the treated sample. This showed the significant change in the wavenumber of $\mathrm{C}-\mathrm{H}$ stretching in the treated sample with respect to the control. The IR frequency at $1635 \mathrm{~cm}^{-1}$ might be due to $\mathrm{C}=\mathrm{O}$ stretching of amino acids in both the control and treated samples. The IR peak at $1589 \mathrm{~cm}^{-1}$ in control might be due to $\mathrm{N}-\mathrm{H}$ bending that was shifted to higher frequency region i.e. at $1596 \mathrm{~cm}^{-1}$ in the treated sample. This showed the increase in the rigidity of $\mathrm{N}-\mathrm{H}$ group in the treated sample with respect to the control. 

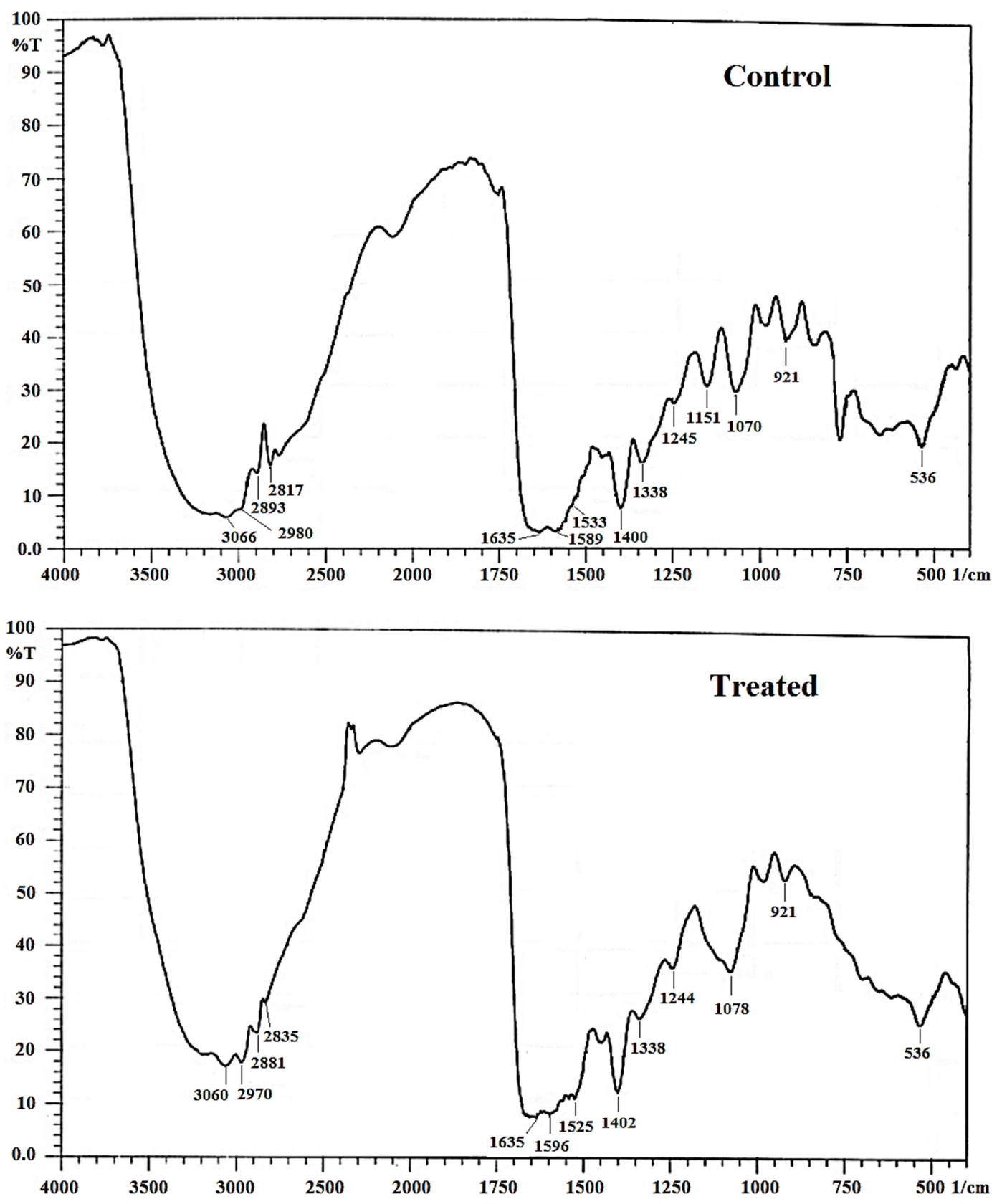

Figure 6. FT-IR spectra of control and treated bio peptone.

Similarly, the vibrational peak at $1533 \mathrm{~cm}^{-1}$ in the control sample might be assigned to the $\mathrm{C}=\mathrm{C}$ stretching, which was sifted to $1525 \mathrm{~cm}^{-1}$ in the treated sample. This might be due to decrease in the bond strength of $\mathrm{C}=\mathrm{C}$ bond in the treated sample as compared to the control. Further, the vibrational peaks at 1400,1338 , and $1245 \mathrm{~cm}^{-1}$ were might be assigned to the $\mathrm{O}-\mathrm{H}$ or $\mathrm{C}-\mathrm{H}$ bending, $\mathrm{N}=\mathrm{O}$ or $\mathrm{C}-\mathrm{N}$ stretching, and $\mathrm{C}-\mathrm{C}$ stretching, respectively in the control sample. These peaks were correspondingly appeared at 1402, 1338, and $1244 \mathrm{~cm}^{-1}$ in the treated sample of bio peptone. The peak at $1151 \mathrm{~cm}^{-1}$ in control sample might be assigned to $\mathrm{C}-\mathrm{O}$ stretching that was not detected in the treated sample. The IR peak at $1070 \mathrm{~cm}^{-1}$ might be assigned to $\mathrm{P}=\mathrm{O}$ stretching of phosphoproteins, which was shifted to upstream region i.e. at $1078 \mathrm{~cm}^{-1}$ in the treated sample. This showed the increased bond strength of $\mathrm{P}=\mathrm{O}$ bond in the treated sample with respect to the control sample. Finally, the IR peaks at 921 and $536 \mathrm{~cm}^{-1}$ were might be assigned to $\mathrm{P}-\mathrm{H}$ bending and out of plane ring deformation, respectively in both the control and treated samples.

Altogether, the FT-IR study suggested the impact of biofield energy treatment on bond strength and force constant of functional groups such as $\mathrm{C}-\mathrm{H}, \mathrm{C}=\mathrm{C}, \mathrm{N}-\mathrm{H}, \mathrm{C}-\mathrm{O}$, and $\mathrm{P}=\mathrm{O}$ with respect to the control bio peptone.

\subsection{UV-Vis Spectroscopic Characterization}

The UV spectra of the control and treated bio peptone are 
shown in Fig. 7. The UV spectrum of control sample showed the absorbance maxima $\left(\lambda_{\max }\right)$ at $259 \mathrm{~nm}$. Similarly, the UV spectra of treated sample showed the $\lambda_{\max }$ at $257 \mathrm{~nm}$ in treated sample. The result showed the similar pattern of $\lambda_{\max }$ in both the control and treated samples. The compound absorbs UV waves due to excitation of electrons from highest energy occupied molecular orbital (HOMO) to the lowest energy unoccupied molecular orbital (LUMO). The $\lambda_{\max }$ altered correspondingly when the HOMO-LUMO gap altered [20]. This suggests that biofield energy treatment did not show any alteration in the $\lambda_{\max }$, which suggested that HOMO-LUMO gap in the treated sample was not altered with respect to the control.

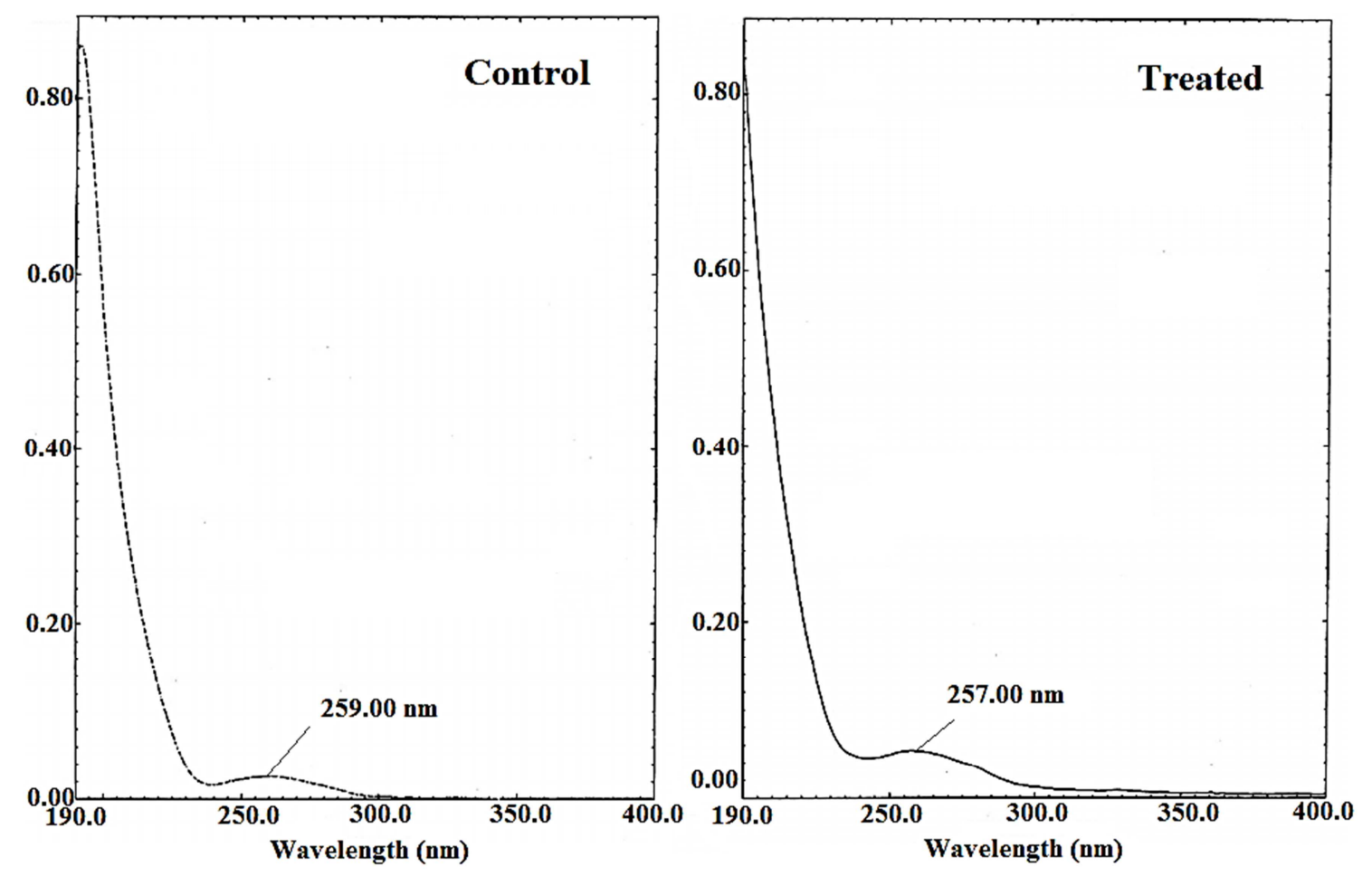

Figure 7. UV spectra of control and treated bio peptone.

\section{Conclusions}

The XRD study revealed the amorphous nature of bio peptone in both the control and treated samples. The particle size analysis showed the increase in the particle sizes i.e. $\mathrm{d}_{50}$ and $\mathrm{d}_{99}$ of the treated bio peptone as compared to the control. The surface area analysis showed the increase in the effective surface area of treated sample by $253.95 \%$ as compared to the control. The DSC study showed the significant increase in the melting temperature of treated sample by $29.59 \%$ as compared to the control. Furthermore, the TGA/DTG study revealed the slight increase in onset temperature of thermal degradation from $181^{\circ} \mathrm{C}$ (control) to $187^{\circ} \mathrm{C}$ in treated sample. This revealed that thermal stability of the treated sample was increased as compared to the control. The FT-IR study revealed the alteration in wavenumber corresponding to $\mathrm{N}-\mathrm{H}$, $\mathrm{C}-\mathrm{H}, \mathrm{C}=\mathrm{C}, \mathrm{C}-\mathrm{O}$, and $\mathrm{P}=\mathrm{O}$ vibrations after biofield energy treatment as compared to the control sample.

Based on these results, it is concluded that Mr. Trivedi's biofield energy treatment had the considerable impact on the various physicochemical and spectroscopic properties of bio peptone. Further, it is expected that the biofield energy treated bio peptone could serve as a better component of culture media with respect to the thermal stability.

\section{Abbreviations}

NIH: National Institute of Health;

NCCAM: National Center for Complementary and Alternative Medicine;

XRD: X-ray diffraction;

DTG: Derivative Thermogravimetry;

TGA: Thermogravimetric Analysis

\section{Acknowledgments}

The authors thank the whole scientific team of MGV pharmacy college, Nashik for allowing the instrumental facility. Authors would also like to acknowledge the Trivedi Testimonials, Trivedi Science, and Trivedi Master Wellness for their consistent support during the study.

\section{References}

[1] Madigan M, Martinko J (2005) Brock biology of microorganisms. (11thedn), Prentice Hall. Upper saddle river, NJ, USA.

[2] Wade J, Graver M (2010) Chemically defined culture medium for neisseria. US $20100003740 \mathrm{~A} 1$. 
[3] Schlegel HG, Zaborosch C, Kogut M (1993). General Microbiology. (7thedn), Cambridge university press, New York, USA.

[4] Todar K (2000) Culture Media for the Growth of Bacteria. University of Wisconins-Madison. http://lecturer.ukdw.ac.id/dhira/NutritionGrowth/culturemedia.ht $\mathrm{ml}$

[5] Atlas RM (2010) Handbook of Microbiological Media. (4thedn), CRC press, Taylor and Francis group, New York, USA.

[6] http://himedialabs.com/TD/RM021.pdf

[7] Rivera-Posada J, Caballes CF, Pratchett MS (2013) Lethal doses of oxbile, peptones and thiosulfate-citrate-bile-sucrose agar (TCBS) for Acanthaster planci; Exploring alternative population control options. Mar Pollut Bull 75: 133-139.

[8] Basu S, Pal A, Desai PK (2005) Quality control of culture media in a microbiology laboratory. Ind J Med Microbiol 23: 159-163.

[9] Ellaiah P, Srinivasulu B, Adinarayana K (2002) A review on microbial alkaline proteases. J Sci Ind Res 61: 690-704.

[10] Rubik B (2002) The biofield hypothesis: Its biophysical basis and role in medicine. J Altern Complement Med 8: 703-717.

[11] Rindfleisch JA (2010) Biofield therapies: Energy medicine and primary care. Prim Care 37: 165-179.

[12] NIH, National center for complementary and alternative medicine. CAM basics. Publication 347. [October 2, 2008]. Available at: http://nccam.nih.gov/health/whatiscam/

[13] Jahn RG, Dunne BJ (1988) Margins of reality: The role of consciousness in the physical world. San Diego, CA: Harcourt Brace Jovanovich.

[14] Rosch PJ (2009) Bioelectromagnetic and subtle energy medicine. The Interface between mind and matter. Longevity, regeneration and optimal health, New York Academy of Science.

[15] Sances F, Flora E, Patil S, Spence A, Shinde V (2013) Impact of Biofield treatment on ginseng and organic blueberry yield. Agrivita, J Agric Sci 35: 22-29.

[16] Trivedi MK, Patil S, Shettigar H, Mondal SC, Jana S (2015) An impact of biofield treatment: Antimycobacterial susceptibility potential using BACTEC 460/MGIT-TB system. Mycobact Dis 5: 189.

[17] Patil SA, Nayak GB, Barve SS, Tembe RP, Khan RR (2012) Impact of biofield treatment on growth and anatomical characteristics of Pogostemon cablin (Benth.). Biotechnology 11: $154-162$.

[18] Trivedi MK, Nayak G, Patil S, Tallapragada RM, Jana S, et al. (2015) Bio-field treatment: An effective strategy to improve the quality of beef extract and meat infusion powder. J Nutr Food Sci 5: 389 .

[19] Trivedi MK, Patil S, Shettigar H, Singh R, Jana S (2015) An impact of biofield treatment on spectroscopic characterization of pharmaceutical compounds. Mod Chem appl 3: 159.

[20] Pavia DL, Lampman GM, Kriz GS (2001) Introduction to spectroscopy. (3rdedn), Thomson Learning, Singapore.

[21] Chauhan A, Chauhan P (2014) Powder XRD technique and its applications in science and technology. J Anal Bioanal Tech 5: 212.

[22] http://www.britannica.com/science/amorphous-solid

[23] Gad SC (2008) Pharmaceutical manufacturing handbook: Production and processes. John Wiley \& Sons, Inc., Publication, New Jersey, USA.

[24] Trivedi MK, Patil S, Mishra RK, Jana S (2015) thermal and physical properties of biofield treated bile salt and proteose peptone. J Anal Bioanal Tech 6: 256.

[25] Groza JR, Shackelford JF (2007) Materials processing handbook. Taylor and Francis group, CRC Press.

[26] Suttiponparnit K, Jiang J, Sahu M, Suvachittanont S, Charinpanitkul T, et al (2011) Role of surface area, primary particle size, and crystal phase on titanium dioxide nanoparticle dispersion properties. Nanoscale Res Lett 6: 27.

[27] Paradkar AR, Bakliwal S (2008). Biopharmaceutics and pharmacokinetics. (3rdedn), Pragati Books Pvt. Ltd., Pune, India.

[28] Kumar S, Tsai CJ, Nussinov R (2000) Factors enhancing protein thermostability. Protein Eng 13: 179-191.

[29] Ratta V (1999) Crystallization, morphology, thermal stability and adhesive properties of novel high performance semicrystalline polyimides. VT. http://scholar.lib.vt.edu/theses/available/etd-051799-162256/u nrestricted/polyimide6.pdf

[30] Qi WH, Wang MP (2004) Size and shape dependent melting temperature of metallic nanoparticles. Mater Chem Phys 88: 280-284.

[31] DeVito SC, Farris CA (1997) Premanufacture notification: Chemistry assistance for submitters. John Wiley \& Sons, INC., New York, USA.

[32] Spear RJ, Maksacheff M (1986) The relationship between ignition temperature and thermal stability for selected primary explosives. Thermochim Acta 105: 287-293.

[33] Smith BC (1998) Infrared spectral interpretation: A systematic approach. CRC Press. 